\title{
Potential of using drainage water for wheat production in Iraq
}

\author{
J. K. Al-Uqaili
}

Agric. \& Biol. Res. Center. P. O. Box. 765, Baghdad, Iraq

\begin{abstract}
A biological experiment was carried out to quantify the effects of drainage water on yield, yield components and ions uptake of wheat. Results showed that yield components viz, tiller and spike no., weight of seed, protein yield, and total yield potential significantly depressed as salinity (ECiw) of irrigation water increased. The 90,75 and $50 \%$ yield potential at irrigation with ECiw's were 4.4, 6.5, and $10.0 \mathrm{dSm}-1$. The results revealed also that ion uptake (N, P and K) was linearly reduced $(r=0.999)$, in contrast, $\mathrm{Na}$ was linearly $(\mathrm{r}=0.977)$ increased, whereas $\mathrm{Ca}$ and $\mathrm{Mg}$ curvilinearrly were depressed $(\mathrm{R}=0.926$ and 0.900$)$ as ECiw of irrigation water increased. The results confirmed that drainage water with salinity level up to $4 \mathrm{dSm}-1$ with leaching fraction (LF) more than $15 \%$ can safely be used for irrigation of wheat crop grown in medium textured soil (Clay loam) under efficient drainage system and suitable agricultural practices.
\end{abstract}

Key words: Saline water, drainage water, yield, ion uptake.

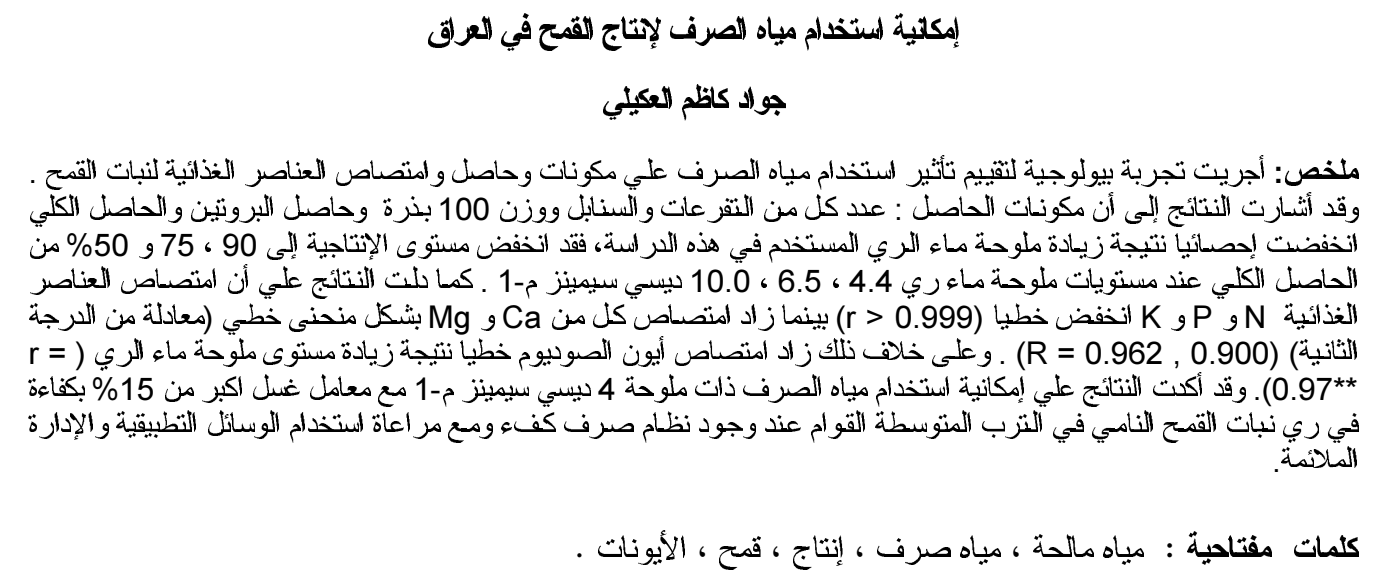

\section{Introduction}

Water is a limiting factor for extended and intensive agricultural production. Because of scarcity of surface water, the use of drainage water will became a more useful strategy in the future for completmental and/or supplemental irrigation in semi-arid and arid regions (Bernstein et al., 1973; Maas, 1985; Sharma et al., 1990; Rhoades et al., 1992). In Iraq, drainage water of Mesopotamia valley contains appreciable amounts of salt ranging from 5.1 to $33.1 \mathrm{gL}^{-1}\left(8-52 \mathrm{dSm}^{-}\right.$ $\left.{ }^{1}\right)$. The chemical composition of drainage water is primarily depending on the location, temperature and season, with $\mathrm{Na}^{+}$, $\mathrm{Ca}^{2+}$ and $\mathrm{Mg}^{2+}$ ions are predominant (Hanna, 1983). Many reports have mentioned the effects of artificial saline ground water on various economic crops (Ayers \& Westcott, 1976; Soliman, 1978; Maas, 1985; Rabie et al., 1985; Gupta \& Yadav, 1986; Bauder et al., 1992; Alsaadawi \& Dahash , 2000). The critical limits saline of water which caused $50 \%$ wheat yield reduction in loamy sand and clay soils were 13.6 and $7.5 \mathrm{dSm}^{-1}$ respectively (Gupta \& Yadav, 1986).

The information about using saline water for irrigation of cereal crops is still limited. Therefore, the aim of this work was to justify the effect of saline drainage water on yield potential, yield components and ions uptake of wheat in addition to its effect on soil salinity build up on medium textured soil. 


\section{Materials and Methods}

An experiment was conducted at Twithia site Agric. \& Biol. Center Baghdad, using drainage water and leaching fraction for irrigation wheat crop (Triticum aestivum L.) cv. Maxipak under lath house conditions.

Ten seeds were grown in pots containing $800 \mathrm{~g}$. gravel, $500 \mathrm{~g}$ sand, and $5 \mathrm{~kg}$ air dried soil. Surface soil sample $(0-30 \mathrm{~cm})$ from Rashidia site, Baghdad Governorate was dried and ground to pass through $2 \mathrm{~mm}$ sieve. The soil was clay loam (214 g sand, $420 \mathrm{~g}$ silt, and $366 \mathrm{~g}$ clay $\mathrm{kg}^{-1}$ ) in texture with $\mathrm{pHe}$ (paste) 7.6, $\mathrm{EC}_{\mathrm{e}} 1.7 \mathrm{dSm}^{-1}$, OM $20.3 \mathrm{~g} \mathrm{~kg}^{-1}$, lime 336 $\mathrm{g} \mathrm{kg}^{-1}$, soluble $\mathrm{Na}$, $\mathrm{Ca}$, and $\mathrm{Mg} 7.1,4.5$ and 2.5 $\mathrm{mML}^{-1}$, sodium adsorption ratio (SAR) 2.7, and $\mathrm{NaHCO}_{3}-\mathrm{P} 7.1 \mathrm{mg} \mathrm{kg}^{-1}$. The irrigation water treatments consisted of eight salinity levels $\left(2-12 \mathrm{dSm}^{-1}\right)$ and canal water was used as control treatment with the salinity $\left(1 \mathrm{dSm}^{-1}\right)$ with nine leaching fractions ranging from 2.5 to $30 \%$ (Table 1 ).

After emergence, the plants were thinned to 5 plants per pot. Three equal split amounts $\left(33,20\right.$, and $25 \mathrm{mg} \mathrm{kg}^{-1}$ soil) of the major nutrients $(\mathrm{N}, \mathrm{P}$ and $\mathrm{K}$ ) were applied at 0,30 and 60 days from sowing date. At maturity stage, the plants were harvested, dried at $65^{\circ} \mathrm{C}$ for $48 \mathrm{~h}$, then straw and seed weight recorded. Total $\mathrm{N}$ was determined by Kjeldahl method (Black, 1965). Protein yield (Py) was calculated according to the following equation :

$$
\mathrm{Py}=\% \text { Seed }-\mathrm{N} \times 5.70 \times \text { Seed yield. }
$$

The mineral plant composition (i.e, P, K, $\mathrm{Ca}$ and $\mathrm{Na}$ ) was estimated according to standard procedures outlined by Chapman \& Pratt, 1961. Soil core composite samples during and after the growing season were analyzed for $\mathrm{EC}_{\mathrm{e}}$ and $\mathrm{SAR}$ in each pot.

\section{Statistical analysis}

The randomized complete block design with six replicates was used in this work. Each block contained nine salinity treatments. The analysis of variance (ANOVA) and simple linear and nonlinear regressions were applied to the data according to Steel \& Torrie (1980).

Table 1. The chemical composition of irrigation water (iw) and leaching fraction (LF\%)used.

\begin{tabular}{|c|c|c|c|c|c|}
\hline \multirow{2}{*}{$\begin{array}{c}\text { Treatment } \\
\mathrm{EC}_{\mathrm{iw}}\left(\mathrm{dSm}^{-1}\right)\end{array}$} & \multicolumn{3}{|c|}{ Cationic concentration $\left(\mathrm{mML}^{-1}\right)$} & \multirow{2}{*}{ SAR } & \multirow{2}{*}{$\begin{array}{l}\mathrm{LF} \\
(\%)\end{array}$} \\
\hline & $\mathrm{Na}$ & $\mathrm{Ca}$ & $\mathrm{Mg}$ & & \\
\hline 1 & 3.8 & 1.4 & 2.7 & 1.9 & 2.5 \\
\hline 2 & 7.3 & 2.7 & 4.2 & 2.8 & 5.0 \\
\hline 3 & 14.6 & 4.6 & 5.6 & 4.6 & 7.5 \\
\hline 4 & 19.3 & 5.3 & 7.5 & 5.4 & 10.0 \\
\hline 5 & 28.5 & 5.4 & 11.1 & 7.0 & 12.5 \\
\hline 6 & 34.1 & 6.8 & 14.0 & 7.5 & 15.0 \\
\hline 8 & 44.5 & 7.6 & 17.0 & 9.0 & 20.0 \\
\hline 10 & 53.4 & 8.1 & 18.7 & 10.3 & 25.0 \\
\hline 12 & 64.0 & 9.0 & 20.7 & 11.7 & 30.0 \\
\hline
\end{tabular}

* Control treatment (canal water).

\section{Results and Discussion}

\section{Yield potential}

Using $\mathrm{EC}_{\mathrm{iw}}$ drainage water with increasing salinity $\left(\mathrm{EC}_{\mathrm{iw}}\right)$ level above $2 \mathrm{dSm}^{-1}$ significantly reduced straw and seed yields, and yield potential (total above ground dry matter production) (straw plus seed) of wheat (Table 2). Irrigation water with salinity of 2 and $3 \mathrm{dSm}^{-1}$ gave significantly high yield potential as compared with canal water as control treatment $\left(1 \mathrm{dSm}^{-1}\right)$. This phenomenon might be due to the fact that 
drainage water may contain more nutrients (i.e., $\mathrm{Ca}$ and $\mathrm{Mg}$ ) than canal water (Table 1). Increasing the $\mathrm{EC}_{\mathrm{iw}}$ level from 3 to 12 $\mathrm{dSm}^{-1}$ drastically depressed the straw seed and yield potential by 100,73 and $66 \%$ of control $\left(1 \mathrm{dSm}^{-1}\right)$ respectively. The yield potential (YP) was linearly decreased by $1.80 \mathrm{~g} \mathrm{pot}^{-1}$ for each $1.0 \mathrm{dSm}^{-1}$ according to the least squares analysis ( $\mathrm{YP}=30.76-$ $\left.1.80 \mathrm{EC}_{\mathrm{iw}}\right)\left(\mathrm{r}=0.970^{* *}\right.$ at $\mathrm{p}<0.01$ level $)$ (Fig. 1). The effects of drainage water on yield components might be attributed to low water availability and / or osmotic inhibitory effect, specific ion toxicity, and/ or low growth rate and low net assimilation (Wicnarajaah, 1990; Bauder et al., 1992). These findings are in agreement with results reported by other workers (Soliman et al., 1978; Mashhady et al., 1982; Maas, 1985 ; Abdul-Halim et al., 1988).

The relative yield potential at any given soil salinity level $\left(\mathrm{EC}_{\mathrm{e}}\right)$ and water salinity $\left(E C_{i w}\right)$ at maturity stage were calculated. The following linear model

$$
\mathrm{Y} / \mathrm{Y} \max =\mathrm{Yr}=1-\mathrm{b}\left(\mathrm{EC}_{\mathrm{e}}-\mathrm{a}\right) \text {, }
$$

where $\mathrm{y}=$ yield, $\mathrm{y} \max =$ yield of non saline control, $\mathrm{a}=$ Salinity threshold, and $\mathrm{b}=$ Slope (regression coefficient). The linear model fits the relationship between yield potential and soil salinity very nicely as judged by the high coefficient of determination $\left(\mathrm{r}^{2}\right)$ and the low standard error of estimate (SE.e). These observations are in line with the results found by others (Maas \& Hoffman, 1977; Rhoades et al., 1992).

The relative wheat yield (Yr) was linearly related to soil salinity $\left(\mathrm{EC}_{\mathrm{e}}\right)$ as follows: $\mathrm{Yr}=100-5.9\left(\mathrm{EC}_{\mathrm{e}}-5.6\right) ;\left(\mathrm{r}^{2}=\right.$ $0.920^{* *}$, and SE.e $=8.6 \%$ )

This equation shows that yield potential is significantly reduced by $5.9 \%$ for each $1.0 \mathrm{dSm}^{-1}$ soil salinity. The relative 90,75 and $50 \%$ yield potential at irrigation water salinity $\left(\mathrm{EC}_{\mathrm{IW}}\right)$ levels with respectively 4.4 , 6.5 , and $10.0 \mathrm{dSm}^{-1}$ and soil salinity $\left(\mathrm{EC}_{\mathrm{e}}\right)$ levels of 7.3, 9.8, and $14.0 \mathrm{dSm}^{-1}$, respectively are shown in Table 3 . Generally the result are in agreement with other results as confirmed by Maas \& Hoffman, 1977 ; Maas, 1985.

Table 2. Yields and yield components of wheat as a function of drainage water.

\begin{tabular}{cccccccc}
\hline $\begin{array}{c}\text { Treatment } \\
\mathbf{E C}_{\mathbf{I W}} \\
\left.\mathbf{d S S m}^{-1}\right)\end{array}$ & $\begin{array}{c}\text { Straw } \\
\text { yield }\end{array}$ & $\begin{array}{c}\text { Seed } \\
\text { yield }\end{array}$ & $\begin{array}{c}\text { Yield potential } \\
\text { (Total biomass) }\end{array}$ & $\begin{array}{c}\text { Wt. Of } \\
\mathbf{1 0 0} \text { seed }\end{array}$ & $\begin{array}{c}\text { Protein } \\
\text { grain yield } \\
\text { mg pot 1 }\end{array}$ & Tiller no. & Spike no. \\
\hline 1 & 17.48 & 7.87 & 25.35 & 2.67 & 975.1 & 3.0 & 2.1 \\
2 & 19.19 & 9.31 & 28.50 & 2.88 & 1230.0 & 3.0 & 2.2 \\
3 & 18.34 & 8.73 & 27.17 & 2.73 & 1141.5 & 3.0 & 2.1 \\
4 & 16.60 & 7.63 & 24.23 & 2.52 & 1046.1 & 2.7 & 2.0 \\
5 & 15.19 & 6.70 & 21.89 & 2.47 & 918.1 & 2.7 & 1.7 \\
6 & 14.18 & 6.04 & 20.22 & 2.38 & 866.3 & 2.7 & 1.7 \\
8 & 11.73 & 5.81 & 17.54 & 2.35 & 844.9 & 2.0 & 1.4 \\
10 & 7.99 & 3.39 & 11.38 & 2.00 & 581.3 & 1.0 & 1.0 \\
12 & 6.94 & 1.75 & 8.69 & 1.75 & 325.0 & 1.0 & 1.0 \\
\hline LSD $^{*}$ & 1.34 & 0.71 & 2.02 & 0.11 & 96.9 & 0.8 & 0.5 \\
\hline
\end{tabular}

* Least significant difference at 0.05 level. 
Table 3. Yield potential (straw + seed) of wheat as related to irrigation water salinity $\left(E C_{i w}\right)$ or soil salinity $\left(E C_{e}\right)$.

\begin{tabular}{|c|c|c|c|c|c|c|c|c|c|c|c|}
\hline \multicolumn{12}{|c|}{ Yield potential (\%) } \\
\hline \multicolumn{2}{|c|}{100} & \multicolumn{2}{|c|}{90} & \multicolumn{2}{|c|}{75} & \multicolumn{2}{|c|}{50} & \multicolumn{2}{|c|}{25} & \multicolumn{2}{|c|}{0} \\
\hline $\mathbf{E C}_{\mathrm{iw}}$ & $\mathrm{EC}_{\mathrm{e}}$ & $\mathbf{E C}_{\mathrm{iw}}$ & $\mathrm{EC}_{\mathrm{e}}$ & $\mathbf{E C}_{\mathrm{iw}}$ & $\mathrm{EC}_{\mathrm{e}}$ & $\mathbf{E C}_{\mathrm{iw}}$ & $\mathrm{EC}_{\mathrm{e}}$ & $\mathbf{E C}_{\mathrm{iw}}$ & $\mathrm{EC}_{\mathrm{e}}$ & $\mathbf{E C}_{\mathrm{iw}}$ & $\mathrm{EC}_{\mathrm{e}}$ \\
\hline 3.0 & 5.6 & 4.4 & 7.6 & 6.5 & 9.8 & 10.0 & 14.0 & 13.6 & 18.3 & 17.0 & 22.5 \\
\hline
\end{tabular}

\section{Yield components}

Tiller no., and spike no. per plant, weight of 100 seeds and protein yield were considered as criteria for yield components. In general, increasing salinity levels of $\mathrm{EC}_{\mathrm{iw}}$ from 1 up to $12 \mathrm{dSm}^{-1}$ statistically decreased those parameters by $67,50,35$ and $66 \%$ respectively (Table 2 ). Also the linear regression results (Fig 1) showd highly significant decreasing rate as 1.05 , $0.62,0.09$, and 69.30 in all yield components (viz tiller and spike no. s plant ${ }^{-}$ ${ }^{1}$, weight of 100 seed $(\mathrm{g})$, and protein yield $\left(\mathrm{mg}\right.$ pot $^{-1}$ with highly significant correlation coefficient $\left(\mathrm{r}>0.917^{* *}\right)$ as irrigation salinity increased by $1.0 \mathrm{dSm}^{-1}$, respectively. This is in agreement with previous studies (Abdel-Halim et al., 1976 ; Abdul-Halim et al., 1988) who found that yield component significantly declined as salinity level increased.

\section{Ion uptake}

The results indicated that drainage water had pronounced effects on ions uptake (i. e, $\mathrm{N}, \mathrm{P}, \mathrm{K}, \mathrm{Ca}, \mathrm{Mg}$, and $\mathrm{Na}$ ). For example, increasing $\mathrm{EC}_{\mathrm{iw}}$ level of irrigation water applied from 1 up to $12 \mathrm{dSm}^{-1}$ gradually depressed N, P and K uptake by 58, 59 and $78 \%$. The absorption pattern of those nutrients followed a linear trend with high reductive rate $(17.20,2.32$ and $52.30 \mathrm{mg}$ pot $^{-1}$ per $\left.1 \mathrm{dSm}^{-1}\right)$, and with high correlation coefficient $\left(\mathrm{r}=0.999^{* *}\right)$ (Fig. 2). On the other hand, the uptake of secondary nutrients such as $\mathrm{Ca}$ and $\mathrm{Mg}$ was directly increased as a parabolic trend upto certain level of ECiw and then sharply declined. The ECiw's maximum of uptake of $\mathrm{Ca}$, and $\mathrm{Mg}$ were 5.4 and $6.0 \mathrm{dSm}^{-1}$, respectively, according to the quadratic model (Fig. 2). In contrast, $\mathrm{Na}$ uptake was significantly increased by using the drainage water. So, using $12 \mathrm{dSm}^{-1}$ level of irrigation, water $\mathrm{Na}$ uptake increased by 2.7 folds as compared with control (canal water, $1 \mathrm{dSm}^{-1}$ ). The $\mathrm{Na}$ uptake followed a linear model with high enhansive rate of $23.63 \mathrm{mg} \mathrm{pot}^{-1}$ per $1 \mathrm{dSm}^{-}$ 1 with high $r$ value $\left(0.977^{* *}\right)$. The synergistic effect of drainage waters on $\mathrm{Na}$ uptake might be explained due to their chemical composition, especially they had high measurable amount of $\mathrm{Na}$ in comparison to other measured cations $(\mathrm{Ca}$ $\& \mathrm{Mg}$ ) (Table 1). 


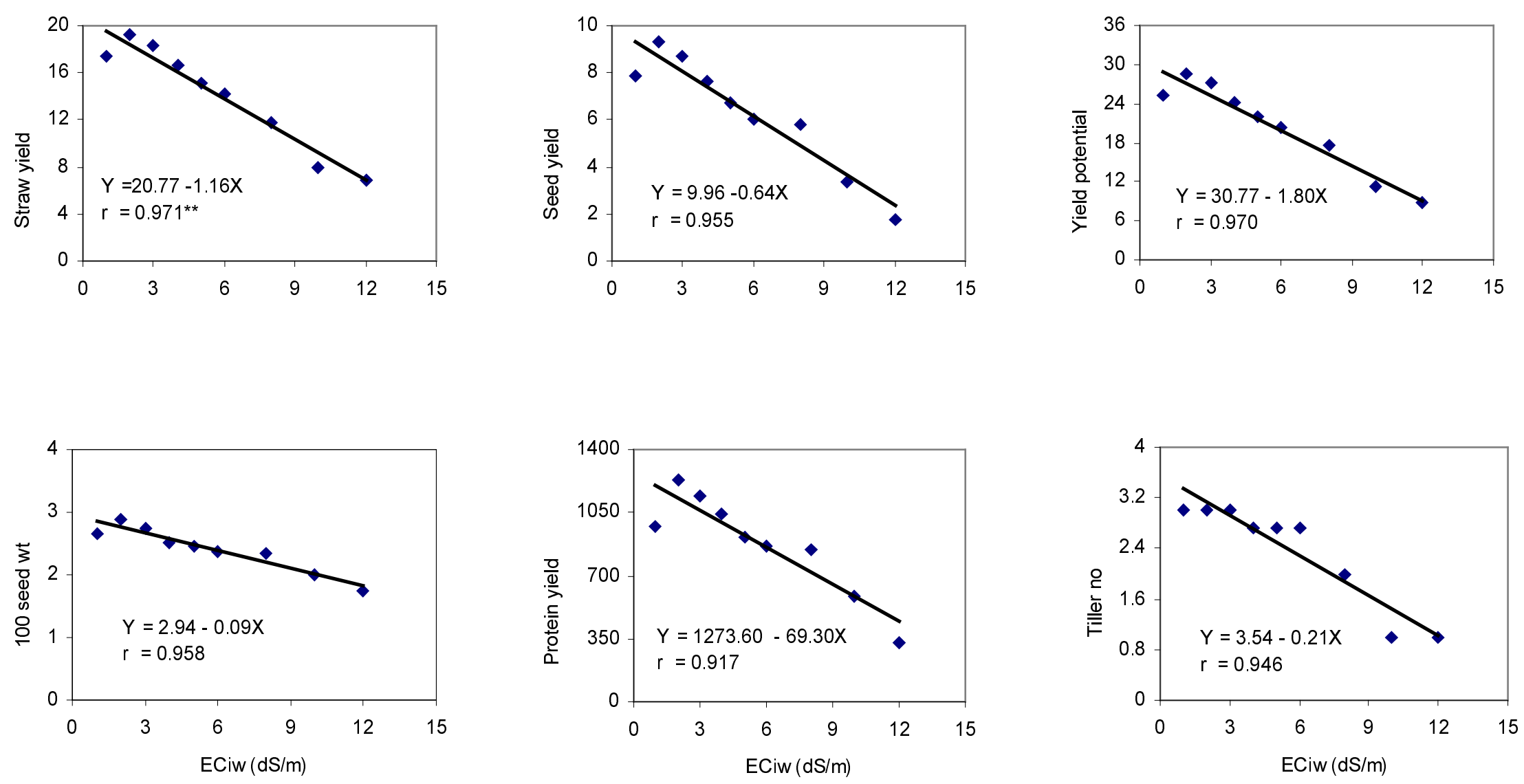

** All correlation coefficients ( $\mathrm{r}$ ) are significant at 0.01 level

Figure 1. Effect of drainage water on yield components of wheat 

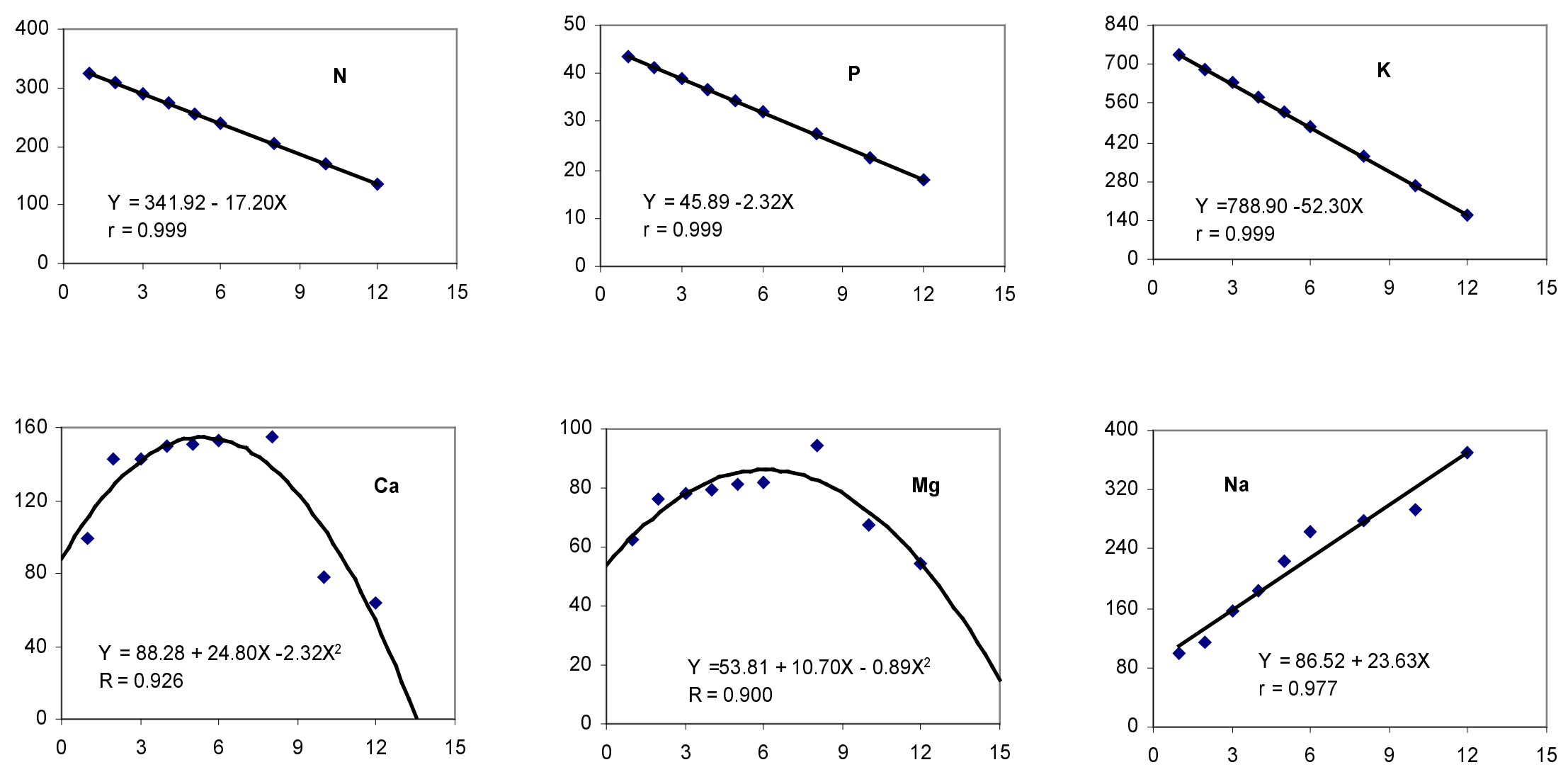

** All correlation coefficients ( $\mathrm{r}$ ) are significant at 0.01 level

Figure 2. Influence of drainage water on ion uptake of wheat (mg/pot.) 
Emir. J. Agric. Sci. 2003. 15 (1) : 36-43

Table 4. Chemical composition of soil solution and soil salinity during growing season of wheat crop

\begin{tabular}{|c|c|c|c|c|c|}
\hline \multirow{2}{*}{$\begin{array}{c}\text { Treatment } \\
\mathrm{EC}_{\mathrm{iw}}\left(\mathrm{dSm}^{-1}\right)\end{array}$} & \multicolumn{3}{|c|}{ Cationic concentration $\left(\mathrm{mML}^{-1}\right)$} & \multirow{2}{*}{ SAR } & \multirow{2}{*}{$\begin{array}{l}\mathrm{ECe} \\
\mathrm{dSm}^{-1}\end{array}$} \\
\hline & $\mathrm{Na}$ & $\mathrm{Ca}$ & $\mathrm{Mg}$ & & \\
\hline 1 & 5.1 & 1.6 & 3.7 & 2.2 & 2.6 \\
\hline 2 & 10.9 & 3.6 & 6.8 & 3.4 & 4.4 \\
\hline 3 & 27.0 & 9.4 & 12.7 & 5.7 & 6.0 \\
\hline 4 & 46.2 & 12.5 & 14.1 & 9.0 & 7.2 \\
\hline 5 & 53.2 & 13.7 & 16.0 & 9.8 & 8.0 \\
\hline 6 & 59.2 & 13.8 & 16.9 & 10.7 & 10.2 \\
\hline 8 & 68.5 & 13.9 & 19.5 & 11.9 & 12.0 \\
\hline 10 & 76.5 & 14.0 & 21.7 & 12.8 & 14.0 \\
\hline 12 & 90.4 & 14.6 & 28.3 & 13.8 & 15.5 \\
\hline $\mathrm{LSD}_{0.05}$ & & & & & 1.5 \\
\hline
\end{tabular}

\section{Soil salinity and soil SAR buildup}

Soil salinity $\left(\mathrm{EC}_{\mathrm{e}}\right)$ gradually increased with increasing salinity level of drainage water used $\left(\mathrm{EC}_{\mathrm{iw}}\right)$ (Table 4$)$. The results of least squares analysis showed that soil $\mathrm{EC}_{\mathrm{e}}$ (y) build up was increasing $\mathrm{EC}_{\mathrm{iw}}$ (X) according to the best linear equation $=$

$$
\mathrm{Y}=2.25+1.18 \mathrm{X}
$$

with high $r$ value (0.992) and low standard error of estimate, SE.e (0.60). So, soil $\mathrm{EC}_{\mathrm{e}}$ incensed by constant rate of 1.18 $\mathrm{dSm}^{-1}$ for each $1 \mathrm{dSm}^{-1}$ of $\mathrm{EC}_{\mathrm{iw}}$. Meanwhile, soil SAR also increased due to the use of drainage water. The linear equation revealed that the soil SAR (y) was related to the SARiw (X) as follows: $(\mathrm{Y}=0.68+1.22 \mathrm{x})$ with high $\mathrm{r}$ and low SE.e $(0.974 * *$ and 1.01$)$

The result confirmed that $\mathrm{EC}_{\mathrm{e}}$ and $\mathrm{SAR}$ of the soil used as growing media increased with use of drainage water for irrigation. Similar results reported by others (Sharmn et al., 1990 and Rhoades et al., 1992 ; Fahad, 2000) found that, in general, both criteria of soil considerably increased with using saline waters for irrigation of cereal crops.

\section{Conclusion}

From the obtained data, we conclude that using drainage water upto $4 \mathrm{dSm}^{-1}$ with leaching fraction (LF) more than $15 \%$ can be safely used for production of wheat under medium growing culture (Clay loam soil ) with efficient drainage system and suitable agricultural practices.

\section{References}

Abdel-Halim, M. A., A. M. Raafat., N. I. Ashur., and T. A. Nour, 1976. Effect of sulfate salinity on growth, chemical constituents and yield of Egyptian wheat. Egypt J. Agron. 1: $201-221$.

Abdul-Halim, R. K., H. M. Salih., A. A. Ahmed., and A. M. Abdul-Rahem, 1988. Growth and development of Maxipak wheat as affected by soil salinity and moisture level. Plant \& Soil 112: 255 - 259 .

Alsaadawi. I. S., and M. I. Dahash. 2000. Response of different barley cultivars to saline water imposed at different stages of growth. Iraqi J. Agric. (Special Issue) 5(2) : $39-46$ (In Arabic).

Ayers, R. S., and D. W. Westcot. 1985. Water Quality for Agriculture. FAO. Irrig. \& Drain. No. 29, Rome, Italy. 
Bauder, J. W., J. S. Jacobsen., and W T. Lantuer, 1992. Alfalfa emergence and survival response to irrigation water quality and soil series. Soil Sci. Soc. Am. J. 56 : 890 - 896.

Bernstein, L., and L. E. Francios, 1973. Leaching requirement studies: sensitivity of alfalfa to salinity of irrigation and drainage waters. Soil Sci. Soc. Amer. Proc. 37: 931 - 943.

Black, C. A. (eds.) 1965. Methods of Soil Analysis. Part 2. Amer. Soc. Agron., Madison, WI.

Chapman, H. D., and P. F. Pratt, 1961. Methods of Analysis for Soil Plant and Waters. Div. of Agric. Sci. Univ. of California.

Fahad, A. A., A. W. Ali, J. J. Al-Khafajii, and A. H. Al-Saadi. 2000. Saline irrigation of corn based on growth stages and its effect on yield and salts accumulation. Iraqi J. Agric. 5(2) : 120 - 129 (In Arabic).

Gupta, I. C., J. S. P. and Yadav, 1986. Crop tolerance of saline irrigation waters. J. Indian Soc. Soil Sci. 34: $379-$ 386.

Hanna, A. B. 1983. Use of saline water in agriculture, land reclamation and leaching efficiency. Arab Sci. Res. J. 11: $41-69$.

Maas, E. V. 1985. Crop tolerance to saline sprinkling water. Plant \& Soil 89 : $273-284$.

Maas, E. V., and G. J. Hoffman, 1977. Crop tolerance - current assessment. J.
Irrig. Drain. Div., ASCE 103 (IR 2) : $115-134$.

Mashhady, A. S., H. I. Sayed., and M. S. Heakal, 1982. Effect of soil salinity and water stresses on growth and control of nitrogen, chloride and phosphate of wheat and triticale. Plant \& Soil $68: 207-216$.

Rabie, R. K., M. K. Matter., A. A. Khamis., and M. M. Mostafa, 1985. Effect of salinity and moisture of soil on growth, nutrient uptake and yield of wheat plant. Soil Sci. Plant Nutr. 31 : $537-545$.

Rhoades, J. D., A. Kandiah., and A. M. Mashali, 1992. The use of saline water for crop production. FAO. Irrig. \& Drain. Div., No. 48, Rome, Italy.

Sharma, D. P., K. N. Singh., K. V. Roa., and P. S. Kumbhare, 1990. Reuse of saline drainage water for irrigation in a sandy loam soil. Sym on Land Drainage for control in Arid and Semi-Arid Regions. 3 : $304-312$, Cairo, Egypt.

Soliman, M. F., I M. Anter., N. F. Soliman., and H. K. Bakhali, 1978. Evaluation of highly salty water for irrigation as tested by wheat and barley plants. Agric. Res. Rev. 56: 21 - 29.

Steel, R. G. B., and J. H. Torrie, 1980. Principles and Procedures of Statistics. McGraw - Hill, Inc. N. Y.

Wicnarajaah, K. 1990. Growth response of phaseolus vulgaris to varying salinity regimes. Exp \& Exp. Botany 30: $141-147$. 